\title{
Az Ectobius vittiventris (COSTA, 1847) (Blattellidae: Ectobiinae) erdeicsótány előfordulása Magyarországon
}

\author{
KINÁL FERENC ${ }^{1}$ és PUSKÁS GELLÉRT ${ }^{2}$ \\ ${ }^{1}$ E-mail: fkinalfferenc@gmail.com \\ ${ }^{2}$ Magyar Természettudományi Múzeum Állattára, 1088 Budapest, \\ Baross utca 13. E-mail: puskas.gellert@nhmus.hu
}

\begin{abstract}
Összefoglalás. 2005-ben Magyarország faunájára új erdeicsótány-faj került elő Budapest parkos belterületén, az Ectobius vittiventris. A rendszeres újabb adatok alapján arra lehet következtetni, hogy ez a mediterrán eredetű, észak felé terjeszkedő csótányfaj megtelepedett a fövárosban és környékén. Gyakran épületekböl kerül elő, noha nem szünantróp faj, feltehetően a fény vonzza be a példányokat. Rajzáscsúcsa hazánkban szeptemberre esik. Nevelési kísérleteinkből kitünik, hogy a lárvastádiumok száma hét, a teljes kifejlődéshez 6 és csaknem 14 hónap közötti időre volt szükség. A fejlődésmenetet feltehetően a nappalok hossza is befolyásolja.
\end{abstract}

Kulcsszavak: entomológia, faunisztika, fenológia, behurcolás, biológiai invázió.

Elfogadva: 2019.04.17.

Elektronikusan megjelent: 2019.05.21.

\section{Bevezetés}

Hazánkban mindössze két csótánynem fajai fordulnak elő a természetben, mindkettő az Ectobiidae (erdeicsótányok) család tagja. A névadó genusz az Ectobius, amelynek ezidáig négy faját és két alfaját jelezték Magyarország területéről: E. erythronotus erythronotus (BURR, 1913), E. erythronotus nigricans RAMME, 1923, E. lapponicus (LINNAEUS, 1758), E. lucidus (HAGENBACH, 1822) és E. sylvestris (PODA, 1761) (VIDLIČKA \& SZIRÁKI 1997). Megjegyzendö, hogy az E. lucidus fenti müben közölt legújabb adata is 55 éves.

Az Ectobius vittiventris (COSTA, 1847) Európában terjedőben lévő erdeicsótány faj. Eredeti areája Korzikától az Appennini-félszigeten, Szicílián, a Balkánon és ÉszakAnatólián keresztül a Kaukázusig húzódik (RAMME 1951, HARZ 1976, GALVAGNI \& BARDIANI 2009). A faj terjedését először Svájcban detektálták, ahol 1985 elött csak az Alpoktól délre, az olasz határhoz viszonylag közel került elő, ettől kezdve azonban az északi országrészben is rendszeresen észlelik (BAUR et al. 2004). Az utóbbi másfél évtizedben dokumentáltan eljutott Németország különböző tartományaiba (BAUR et al. 2004, KÖHLER 2006, PFEIFER 2012), Ausztriába (ZIMMERMANN 2014) és Szlovákiába (VIDLIČKA 2014). Az újonnan meghódított területeken kertes, parkos városi élőhelyeken jelent meg. 
Szabadban élő faj, ennek ellenére rendszeresen került elő épületekből, ahol azonban legfeljebb néhány napig képes túlélni (BAUR et al. 2004). Nincsenek adatok arra vonatkozóan, hogy volna humánegészségügyi jelentősége. Kellemetlenséget leginkább azzal okozhat, hogy összetéveszthető a némileg hasonló megjelenésü, épületekben élő, kártékony német csótánnyal (Blattella germanica (LINNAEUS, 1767)). Az E. vittiventris épületekbe jutását megfelelő nyílászárókkal, szúnyoghálóval lehet megakadályozni (UÇKAY et al. 2009).

Az alábbiakban Magyarország faunájára újként közöljük az E. vittiventris fajt, bemutatjuk a felismeréshez szükséges alaktani jellemzőit, elterjedését, fenológiáját, továbbá - laboratóriumi kísérleteink eredményeként - fejlődését és táplálkozását. Végül taglaljuk az erdeicsótányok és a fény kapcsolatát.

\section{Anyag és módszer}

Vizsgált anyag (L: lárva a stádium számával):

Budapest II., Hankóczy u., leg. KIRÁLY Z. 2005.VIII.27. (1ठ̋), X.27. (1ठ̋), X.28.

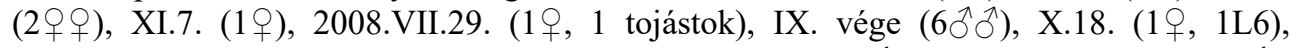

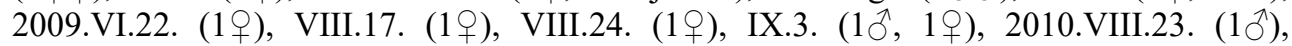

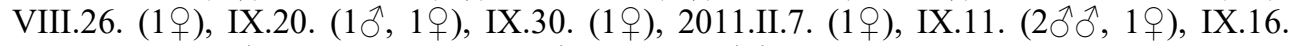

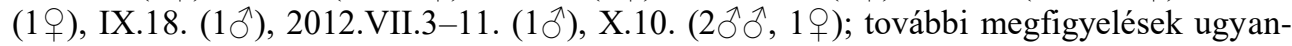

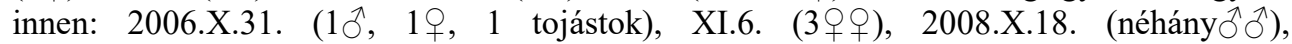
2010.VIII.24. (1§ึ, 1L7), VIII.26. (1ㅇ, 2L7), VIII.27. (1우 tojástok-kezdeménnnyel), VIII.31. (1L7), IX.3. (1 $\overbrace{}^{\Uparrow})$, IX.6. (1L7), IX.13. (1ठ), X.25. (2우, egyikük tojástokkezdeménnyel), XI.5. (19);

Budapest II., Fény u., leg. Szentkirályi F. 2010.IX.30. (19), X.8. (1ठ̋);

Budapest II., Pasaréti út, leg. PAUlovKIN A. 2016.IX.27. (3ㅇq);

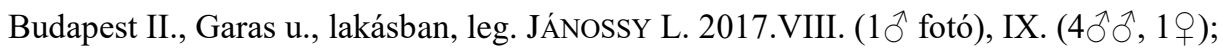

Budapest XI., Sas-hegy, hálózás/egyelés, leg. KINÁL F. 2012.IX.5. (19, 1L7); hálózás, leg. PUSKÁs G. 2017.IX.18. (1ठ̋);

Budapest XI., Olajbogyó u., kertben és lakásban, leg. KRIZSÁN K. 2018.VII.25. (1q fotó), VIII-IX. (2ત̂̉, 4 웅);

Budapest XI., Tétényi út, IV. emelet, leg. Tóтн B., lakásban (fürdőszoba) 2018.VIII.21. (1ㅇ), fénycsapda 8W UV fénycsővel 2018.IX.13. (1우);

Budapest XII., Székács u., leg. KATONA Á., lakásban fotó 2012.X.17 (1q), lakásban XI. $(2 \hat{\jmath}, 7$ 우우);

Budapest XII., Béla Király út, terasz, leg. NAGY B. 2013.IX.7. (1ठ);

Budapest XII., Galgóczy u., leg. MAKAY A., fényre 2016.IX.12. (4ठึ);

Budapest XVI., Akácfa u., leg. BABOCSAY G. 2018.IX. eleje (1ð), X. eleje (4q + ); $(1+$ );

Budapest XVIII., Pestszentlőrinc, leg. KIRÁLY Z. 2012.IX.30. (1ð̋ 5q \&), 2013.VI.19.

Budakeszi, Vásárhely u., lakásban, leg. JÁNOSSY L. 2017.VIII.30. (1 + tojástokkal). 
A példányok többsége a Magyar Természettudományi Múzeum Állattárában található. A 2015 előtt gyüjtött példányok a Magyar Tudományos Akadémia Agrártudományi Kutatóközpont Növényvédelmi Intézet (akkor még MTA Növényvédelmi Kutatóintézet, NKI) Júliamajori Kísérleti Telepének gyüjteményében lettek elhelyezve, ez a gyüjtemény azonban 2015-ben a Magyar Természettudományi Múzeumba került (NAGY 2016). PAULOVKIN ANDRÁS valamint MAKAY ATTILA gyüjtései KINÁL FERENC magángyüjteményében lettek elhelyezve. A tenyésztési kísérletek miatt a felsoroltak közül néhány példány nem található meg a gyüjteményekben.

A példányok határozását HARZ (1976) valamint BAUR et al. (2004) munkái alapján végeztük el.

A 2005 és 2018 között gyüjtött adatok (41ઠึð, 57우, 7 nagy lárva és 3 tojástok) alapján vizsgálhattuk a faj hazai populációjának fenológiáját (a 2 tojástok-kezdeményt nem vettük figyelembe). A szezonális dinamika bemutatásához összegeztük és diagramon ábrázoltuk az egy-egy naptári hónapban észlelt egyedszámokat.

Mivel a nőstények többsége néhány napon belül tojástokot fejlesztett, megpróbálkoztunk a kinevelésükkel. A nevelési kísérletek az MTA NKI Júliamajori Kísérleti Telepén történtek 2008 és 2010-11 években. A kézhez kapott E. vittiventris példányok (többnyire imágók) egy részét két kisebb méretü üveghengerben $(10 \mathrm{~cm}$ átmérőjü, $12 \mathrm{~cm}$ magas egérpohár) helyeztük el életmódjuk megfigyelése és nevelési, tenyésztési kísérletek céljából. Nedvesített talajon (homok és virágföld 3:1 arányú keverékén) szobahőmérsékleten tartottuk őket, búvóhelynek kevés kéreg és avarlevél szolgált. A tenyészetet hetente ellenőriztük, ezért nem láttuk, hány tojástokot raktak le. Mivel az egy-egy tojástokból kelő példányok nem voltak elkülönítve, az egyes kohorszok esetében a leggyorsabban fejlődő (legnagyobb) lárvákon észleltük a vedlési eseményeket, így a stádiumok hossza ezekre vonatkozik.

Az E. vittiventris tenyészetek ellátására egyszerre háromféle táplálékot adtunk: 1) az idénynek megfelelö lédús (héjuktól részben megfosztott) gyümölcsöket és terméseket, pl. körte szilva, barack, cseresznye, szőlő, mandarin, naspolya, almaszelet, paradicsom, paprika; 2) húsfélének felvágottat (párizsit) adtunk; 3) próbaképp az NKI területén széles körben használt félmesterséges táptalajt (NAGY 1970) is felkínáltuk.

\section{Eredmények és megvitatás}

\section{$A z$ Ectobius vittiventris Magyarországon}

Javasolt magyar név: kertvárosi erdeicsótány.

Az első magyarországi E. vittiventris példányt KIRÁLY ZOLTÁN gyüjtötte budapesti lakásában (II. kerület, Hankóczy u.) 2005. augusztus 27-én. A fajt azóta számos alkalommal gyüjtötték vagy figyelték meg. Ezidáig csak Budapest és Budakeszi kertvárosi övezeteiből került elö, az adatok többsége a budai kerületekből származik (1. ábra). A gyüjtések és megfigyelések rendszeressége arra utal, hogy a faj mára már megtelepedett a fövárosban és környékén. 


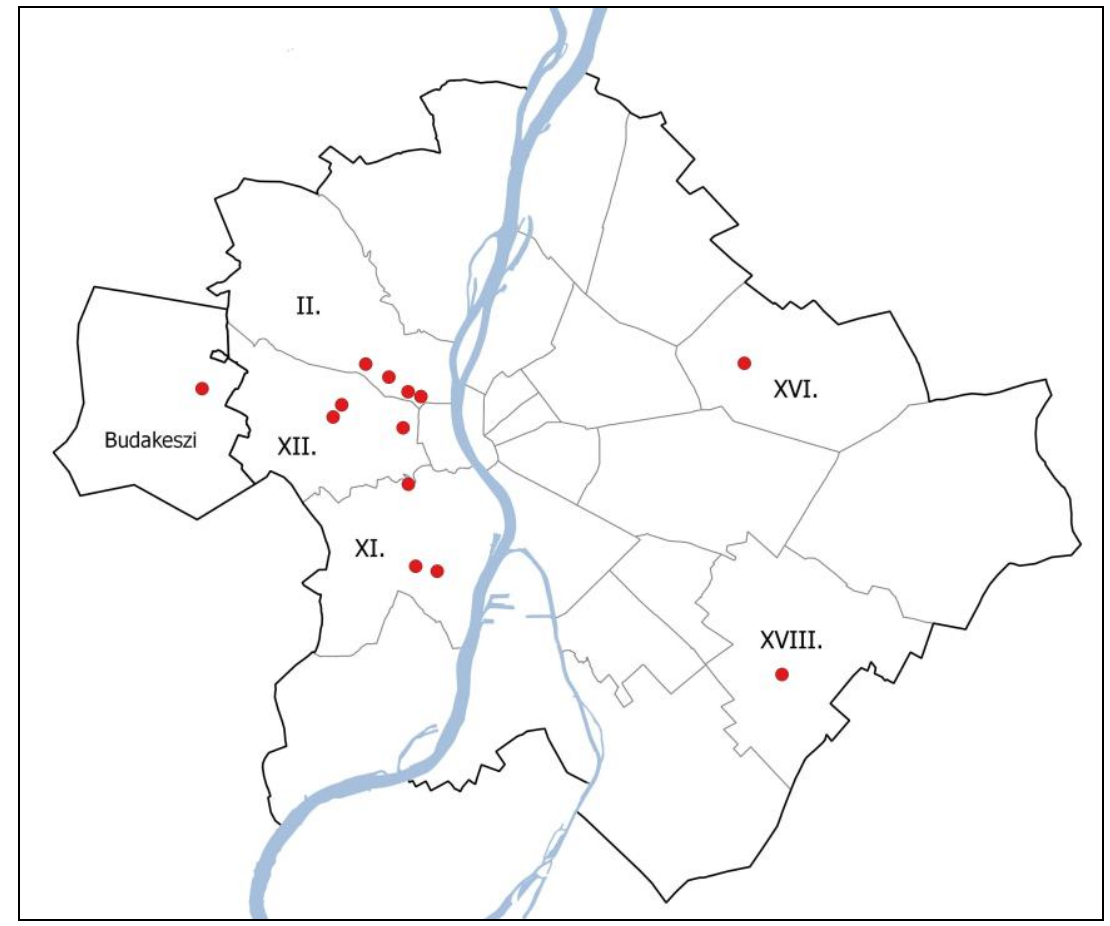

1. ábra. Az Ectobius vittiventris gyüjtési helyei Budapesten és környékén.

Figure 1. Collecting sites of Ectobius vittiventris in the Budapest agglomeration.

\section{Felismerés, külsö morfológia}

Az E. vittiventris testének és végtagjainak színe rendszerint okkersárga (2. ábra). A 0

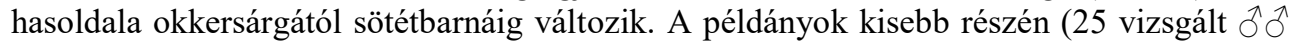
közül mindössze 2 esetében) az előtorpajzson sötétbarna, határozatlan szélü középfolt található (az elötorpajzsról azonban hiányzik a Blattella germanica fajra jellemzö két párhuzamos sötét szalag). Szárnyai hosszúak, mindkét ivarnál túlnyúlnak a test végén. A közép- és utóhát részben feketés, a potrohhát legalább részben feketés. A $\delta^{\lambda}$ hetedik hátlemezén található illatmirigy okkersárga, ovális, nem éri el a hátlemez hátsó szélét, nincs benne csapvagy dudorszerü kiemelkedés vagy szörpamacs. A hím utolsó haslemeze (szubgenitális lemez) aszimmetrikus, egy stylussal a csúcsán. A stylus nagy, részben sürủ, hajszerü szörzettel borított (HARZ 1976, BAUR et al. 2004). 


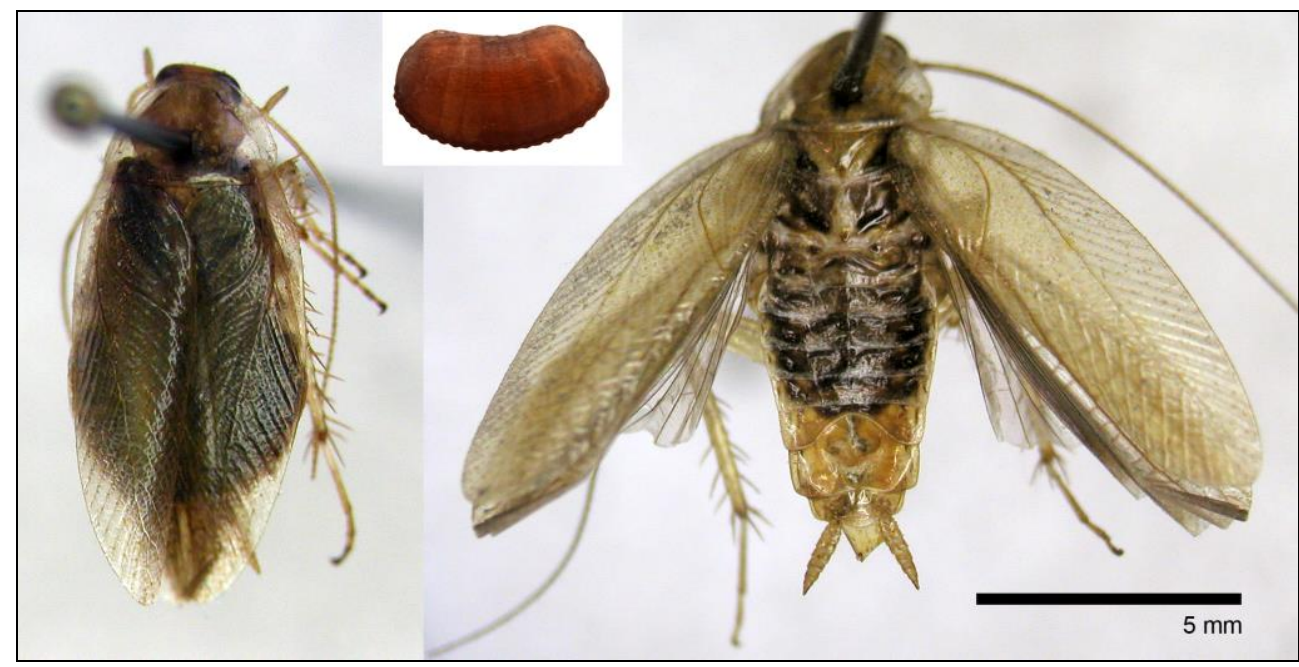

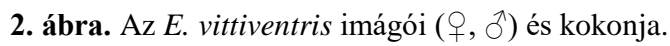

Figure 2. Habitus of E. vittiventris: adult,$+ \hat{O}$ and ootheca.

Külső megjelenése némileg hasonló az épületekben élő, kártékony német csótányhoz (B. germanica) de a német csótány előtorán két párhuzamos sötét hosszanti sáv található, valamint különbözik a potrohhát illatmirigye és a potroh vége is. A hazai erdeicsótányok közül hasonlóan világos, barnás színü az E. e. erythronotus előtorpajzsa. Az utóbbi faj azonban kisebb termetü, a $\widehat{\jmath}$ testének alsó oldala és végtagjai sötét színủek, illatmirigye eltérő alakú, a közepén szőrpamaccsal, a q szárnya rövidebb, rendszerint nem éri el a cercus végét.

Az E. vittiventris fejlettebb lárváinak színe okkersárgától sötétbarnáig változik, az elöhát szegélye valamint a szárnykezdemények okkersárgán áttetszőek vagy átlátszatlanok. A némileg hasonló $B$. germanica lárvák sötét színüek, hátukon világos középsávot viselnek.

A Magyarországon gyüjtött példányok néhány morfometriai mutatója az 1. táblázatban látható. BAUR et al. (2004) adataival összevetve a magyarországi példányok átlagosan kisebbek, mint a svájciak.

\section{Elterjedés, terjeszkedés}

Az E. vittiventris eredeti areája az európai Mediterráneum, Észak-Anatólia és a Kaukázus (HARZ 1976). A faj terjedését először Svájcban detektálták, ahol 1985 elött csak az Alpoktól délre került elö. A terjedés főbb ismert állomásai a következők:

1985: Svájc Alpoktól északra eső területei (BAUR et al. 2004)

2001: DNy-Németország (Baden-Württemberg) (BAUR et al. 2004)

2005: Magyarország (Budapest)

2006: K-Németország (Jena, Türingia) (KöHLER 2006) 
2009: Ausztria (Voralberg) (ZIMMERMANN 2014)

2011: Ny-Németország (Rajna-vidék-Pfalz) (PFEIFER 2012)

2012: Szlovákia (Pozsony) (VIDLIČKA 2014)

A felmelegedés következtében a faj feltételezhetően tovább terjeszkedik É-ra, főleg városi környezetben (MUELLER et al. 2008).

1. táblázat. A vizsgált $E$. vittiventris példányok testméretei $(\mathrm{mm})$ száraz preparátumok alapján $\left({ }^{*} \mathrm{~N}=7\right.$, egy további tojásokkal teli + testhossza $\left.11,5 \mathrm{~mm}\right)$.

Table 1. Body sizes (in $\mathrm{mm}$ ) of E. vittiventris specimens based on dry material $(* \mathrm{~N}=7$, body lenght of a further gravid $q: 11,5 \mathrm{~mm})$.

\begin{tabular}{lll}
\hline & \multicolumn{1}{c}{$(\mathbf{N}=\mathbf{1 3})$} & $+q(\mathbf{N}=\mathbf{1 9})$ \\
\hline Testhossz / Body length & $9,3(8,1-11,5)$ & $7,7(6,8-8,1)^{*}$ \\
Előhát hossz / Pronotum length & $2,1(2,0-2,2)$ & $2,4(2,2-2,6)$ \\
Előhát szélesség / Pronotum width & $3(2,9-3,2)$ & $3,3(3,1-3,7)$ \\
Elülső szárnyhossz / Elytra length & $9,7(9,2-10,6)$ & $8,1(7,7-8,7)$ \\
Elülső szárnyszélesség / Elytra width & $2,7(2,6-3,0)$ & $2,7(2,5-2,9)$ \\
Elülső szárnyhossz : elóhát hossz arány & $4,5(4,3-4,9)$ & $3,4(3,2-3,6)$ \\
\hline
\end{tabular}

VIDLIČKA (2014) térképen mutatta be a faj európai areanövekedését. A svájci, németországi és ausztriai publikált adatok alapján a 2012 óta ismert pozsonyi populáció eredetét egy nyugat felöl keletre irányuló terjedéssel magyarázta. Ennek ellentmondani látszik, hogy Budapesten már 2005 óta folyamatosan ismert a jelenléte. A csoport alulkutatottsága miatt feltételezhető, hogy a terjedésnek csupán néhány állomása dokumentált, az újonnan megtelepedett állományainak jelentős része továbbra is ismeretlen lehet. Valószínü, hogy a faj terjedésében kulcsszerepet játszanak a rendszeres, véletlen emberi behurcolások.

Magyarországon az utóbbi években számos alkalommal gyüjtöttek mediterrán eredetü fajokat az Orthoptera, Blattodea, Mantodea és Dermaptera rendekből (BoDOR 2014, MURÁNYI \& PUSKÁS 2018, PUSKÁS 2018). Ezek jelentős része kertészetekből származik, ahová bizonyíthatóan olaszországi növényszállítmányokkal érkeztek (BODOR 2014, BOGNÁR FERENC, GÁL KURSZÁN, HORVÁTH DÁVID, SOÓS TAMÁS és TÓTH SZABOLCS szóbeli közlései). Az E. vittiventris faj Magyarországra való behurcolásának is ez az egyik lehetséges útja.

\section{Táplálkozás}

Megfigyeléseink szerint az E. vittiventris példányok nem fogyasztottak szilárd állagú táplálékot, így a számos rovar tartására alkalmas félszintetikus táptalajt sem. Csak folyékony vagy könnyen oldható táplálékot fogyasztottak. Más hazai fajok (E. erythronotus, Phyllodromica maculata) fejlett lárvái és imágói hasonlóan táplálhatók, a félmesterséges (részben nedves állagú) táptalajt csak akkor fogyasztották, ha egyéb táplálékot nem kaptak, egyébként a két nem fajainak táplálkozása laboratóriumi körülmények között közel azonos (KINÁL F. megfigyelései). 


\section{Egyedfejlödés}

A tenyészeteket (változó) szobahőmérsékleten tartottuk, ezért csak korlátozottan következtethetünk eredményeinkből a szabadföldi populációk fenológiájára. A nevelési kísérletek főbb eseményeit a 2. táblázat mutatja be.

2. táblázat. Főbb események a négy nevelési kísérletben.

Table 2. Main events in the rearing experiments.

\begin{tabular}{|c|c|c|c|}
\hline tenyészet & & tum / date & esemény / event \\
\hline 1. & 2008. & X.18. & 1 + tenyészetbe $/ 1$ i into culture \\
\hline 1. & & X.22. & kokont fejlesztett / developing an ootheca \\
\hline 1. & 2009. & II-III. & $\begin{array}{l}4 \text { lárva kelt (nem sikerült öket kinevelni) / hatching } 4 \text { larvae } \\
\text { (have not became adult) }\end{array}$ \\
\hline 2. & 2010. & VIII.26-IX.14. & $\begin{array}{l}\text { számos fejlett lárva, } \hat{\delta} \hat{\sigma}, q++ \text { tenyészetbe / numerous large } \\
\text { larvae, } \hat{\partial} \hat{\partial}, 00 \text { into culture }\end{array}$ \\
\hline 2. & & IX.24. & 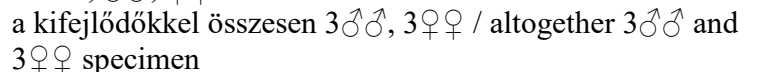 \\
\hline 2. & & XI.25. & $\begin{array}{l}16 \text { órakor } 19 \text { a talaj felszínén üreget kapart, ebbe } 13 \text { perc } \\
\text { múlva kokont rejtett (a későbbiekben nem volt lárvakelés) / } \\
16 \mathrm{~h}: 1 \text { q made a hole on the ground surface, in } 13 \text { minutes } \\
\text { placed an ootheca in it (later no larva hatching happened } \\
\text { from it) }\end{array}$ \\
\hline 3. & 2010. & VIII.26. & 2 fejlett lárva tenyészetbe / 2 large larvae into culture \\
\hline 3. & & IX.6. & egy további fejlett lárva behelyezve / a further larva into \\
\hline 3. & & IX.2-24 & $\begin{array}{l}1 \hat{\partial}, 1 q \text { imágót neveltünk ki belölük } / 1 \hat{O}, 1+\text { adults reared } \\
\text { from them }\end{array}$ \\
\hline 4. & 2010. & X.25-XI.5. & $3 q+$ tenyészetbe / $3 q q$ into culture \\
\hline 4. & & XII.2. & $\begin{array}{l}\text { az egyik példány háromnegyed részt kész kokont cipelt / a } \\
\text { female carrying an ootheca being } 3 / 4 \text { ready }\end{array}$ \\
\hline 4. & & XII.23-30. & $\begin{array}{l}3 \text { lárva kelt („A kohorsz”), melyekböl } 3 \text { 우 fejlődött ki / } \\
\text { hatching } 3 \text { larvae ('cohort A'), later } 3 \text { 우 developed from } \\
\text { them }\end{array}$ \\
\hline 4. & 2011. & I.27-II.3. & $\begin{array}{l}\text { az utolsó tenyészetbe vont } q \text { elpusztult / mortality of the } \\
\text { last starter }+\end{array}$ \\
\hline 4. & & V.19-26. & $\begin{array}{l}4 \text { lárva kelt („B kohorsz”), melyekből } 10 \text { fejlödött ki / } \\
\text { hatching } 4 \text { larvae ('cohort B'), later } 1 \hat{\text { developed from }} \\
\text { them }\end{array}$ \\
\hline 4. & 2012. & I.5-12. & $\begin{array}{l}6 \text { lárva kelt („C kohorsz”), melyekből } 2 \delta^{\lambda} \delta^{\Uparrow} \text { fejlödött ki / } \\
\text { hatching } 6 \text { larvae ('cohort C'), later } 2 \delta^{\lambda} \delta^{\lambda} \text { developed from } \\
\text { them }\end{array}$ \\
\hline
\end{tabular}

Nevelési kísérleteinkből kitünik, hogy a tojások - eltérően az E. lapponicus fajtól (BROWN 1973) - nem igényelnek (obligát) diapauzát bár az egyes tojástokok kelése aszinkronitást mutat. 
Megfigyeléseink azt mutatják, hogy a lárvák hét stádium után váltak imágóvá. Ez kettővel több stádium, mint ami az E. lapponicus, illetve egyel több, mint a - hazánkban nem élö - E. pallidus fajok esetében ismert (BROWN 1969). Az E. vittiventris lárvastádiumainak hosszát részletesebben a 3. táblázat és a 3. ábra mutatja be. Mivel a példányok nem voltak elkülönítve, a három kokonból kelő (három kohorsz) leggyorsabban fejlődő lárvákra vonatkoznak a feljegyzések. Az egyes stádiumok hossza 17 és 147 nap között váltakozott, egyegy kohorszban az átlag 26 és 59 nap között volt. A lárvák mindhárom kohorszban nyárra fejlődtek ki, de míg a télen kelteknél 6 illetve 7 hónap volt az ehhez szükséges idő, addig a tavasz végén kelt kohorsznál csaknem 14 hónap. Ez arra utal, hogy a nappalok hossza is befolyásolhatja a lárvafejlődést. Ismert jelenség, hogy a fotoperiodizmus hatással lehet a csótányok fejlödésére, noha kevés vizsgálat foglalkozott ezzel a témával (BROWN 1973, WASSMER \& PAGE 1993).

3. táblázat. Az E. vittiventris lárvastádiumainak hossza (nap) a három sikeresen kinevelt kohorszban (az egyes kohorszok leggyorsabban fejlődő példányai).

Table 3. Larval stadium lengths (days) of E. vittiventris in the three successfuly reared cohort (the fastest developing specimens in each cohort).

\begin{tabular}{llll}
\hline $\begin{array}{lll}\text { lárvastádium / kohorsz } \\
\text { larval stadium / cohort }\end{array}$ & A & B & C \\
\hline L1 & 21 & 26 & 28 \\
L2 & 28 & 50 & 41 \\
L3 & 21 & 21 & 23 \\
L4 & 42 & 21 & 22 \\
L5 & 35 & 99 & 31 \\
L6 & 41 & 147 & 21 \\
L7 & 28 & 48 & 17 \\
átlag / mean & 30,9 & 58,9 & 26,1 \\
\hline összes / sum & 216 & 412 & 183 \\
\hline
\end{tabular}

\section{Fenológia}

A 2005 és 2018 között gyüjtött 105 példány és 3 tojástok adatai alapján vizsgálhattuk a faj szezonális dinamikáját (4. ábra). A fenológiai adatok arra utalnak, hogy az E. vittiventris Magyarországon szemivoltin faj kétéves fejlődéssel. BAUR et al. (2004) Svájcban szintén kétéves életciklust feltételeztek fejlődésére, mivel az apró lárvák nyáron, nagyobb lárvák télen találhatók. Más, Európában őshonos Ectobius fajok hasonló fenológiát mutatnak: az E. lapponicus és az E. pallidus az első évben tojás alakban, a másodikban lárvaként telel át (BROWN 1969, HOLUŠA \& KOČÁREK 2000). 


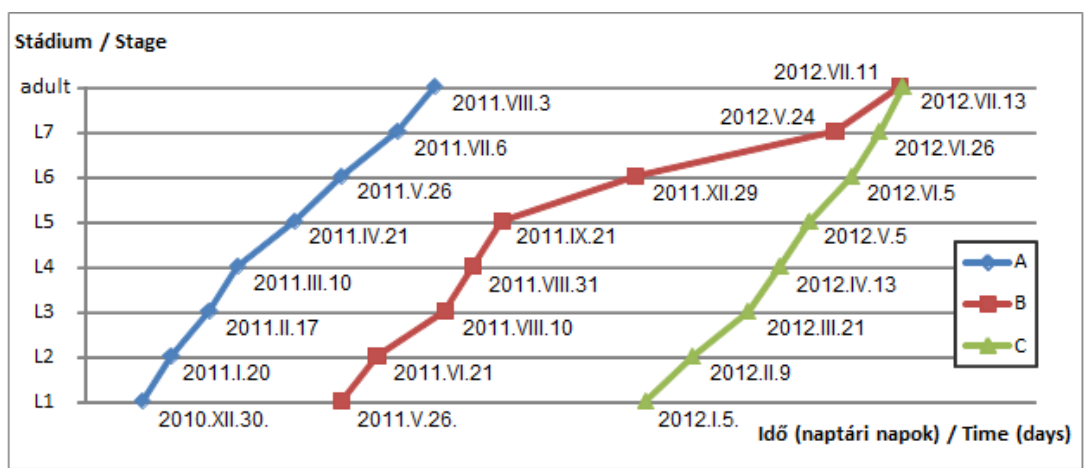

3. ábra. Az E. vittiventris lárvák fejlődése a három sikeresen kinevelt kohorszban (az egyes kohorszok leggyorsabban fejlödő példányai).

Figure 3. Developing of E. vittiventris in the three successfuly reared cohort (the fastest developing specimens in each cohort).

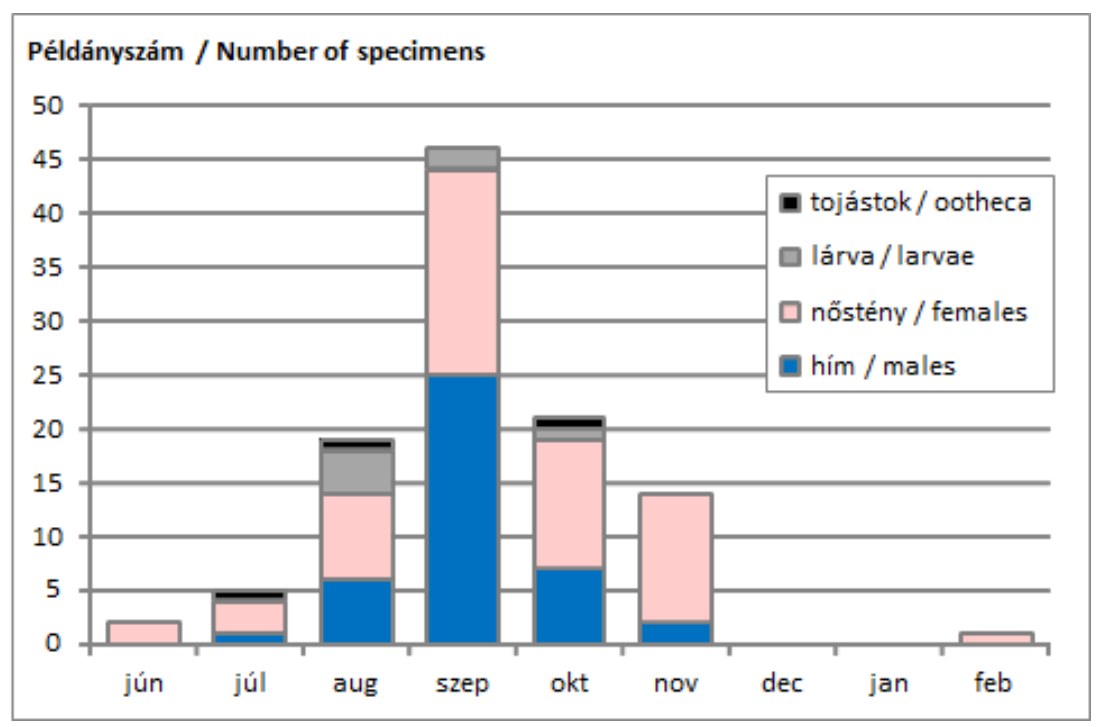

4. ábra. Az E. vittiventris fenológiája a 2005 és 2018 között gyüjtött példányok alapján.

Figure 4. Phenology of E. vittiventris based on the collected specimens between 2005 and 2018 .

BAUR et al. (2004) Svájcban augusztusi rajzáscsúcsot mutattak ki. Ehhez képest a budapesti populáció esetében későbbi, szeptemberi csúcsot tapasztaltunk. Kis egyedszámmal már júniustól egész nyáron észlelhetők imágók, a szeptemberi észlelések azonban kiugróan 
magasak. Összel a hímek egyedszáma gyorsan csökken, míg nőstények októberben és novemberben is a szeptemberihez hasonlóan magas számban kerültek elő.

Egy 2011. február 7-én gyüjtött példány alapján kiderült, hogy - legalábbis a nőstény ritkán áttelelhet. Ezen az adaton kívül hazánkban nincsenek téli vagy tavaszi észlelések. Nevelési kísérleteink is alátámasztják, hogy kedvező körülmények között a nőstények legalább két-három hónapig élhetnek. Svájcban május és december között gyüjtötték az imágók túlnyomó többségét, míg a lárvák egész évben elöfordultak (bár télen nagyon kis egyedszámmal) (BAUR et al. 2004).

\section{Az erdeicsótányok és a fény}

Az E. vittiventris - a Magyarországon előforduló más Ectobius és Phyllodromica fajokhoz hasonlóan - nem él épületekben, ilyen feltételek között csupán néhány napig képes túlélni (BAUR et al. 2004). Ennek ellentmondani látszik, hogy legtöbbször lakásokból kerül elő. Valószínü, hogy a fény vonzza a példányokat az épületekbe. Más erdeicsótány fajok esetében is igazolt a pozitív fototaxis jelensége (BELL et al. 2007). Hazánk természetközelibb élőhelyein az $E$ sylvestris, E. laponicus, $E$ e. erythronotus, $E$. $e$. nigricans is gyakran előkerülnek az Erdészeti Fénycsapda-hálózat gyüjtéseiből vagy egyéb (rovarászati célú) fényforrások mellöl, föleg hím példányok (KINÁL F. nem közölt adatai). $\mathrm{Az}$ E. vittiventris azonban az előbbi fajoktól eltérően városi (budapesti) parkos-kertes negyedekben telepedett meg, ezért tudja az épületekből kiáradó fény a lakásokba csalni őket.

\section{Konklúzió}

Az elmúlt évek adatai egyértelmúen arra utalnak, hogy az E. vittiventris megtelepedett a fővárosi agglomeráció zöldövezetében. Az európai areanövekedés alapján feltételezhető, hogy jelen van vagy fel fog bukkanni a jövőben az ország más területein is, elsősorban kertvárosi környezetben. Szabadban élö faj, azonban rendszeres megjelenése a lakóépületekben riadalmat okozhat. A szünantróp csótányokra jellemző humánegészségügyi jelentősége (allergiás reakciók, patogének terjesztése) nem ismert.

Köszönetnyilvánítás. Köszönjük NAGY BARNABÁSnak (Magyar Természettudományi Múzeum) a faj meghatározásához és a kézirat összeállításához nyújtott segítségét, valamint SzENTKIRÁLYI FERENCnek az Erdészeti Fénycsapda Hálózat csótány anyagának átadását. Köszönet illeti KIRÁLY Zoltánt, Babocsay Gergelyt, Csorba Gábort, JÁnossy Lászlót, Katona ÁGnest, Krizsán Krisztinát, MAKay AtTilát, PAUlovkin ANDrÁst, SZENTKIRÁlyi Ferencet valamint Tóth BalÁzst a szerzőkhöz eljuttatott példányokért. 


\section{Irodalomjegyzék}

Baur H., Landau LÜScher, I., Müller G., Schmidt M. \& Coray A. (2004): Taxonomie der Bernstein-Waldschabe Ectobius vittiventris (A. CosTA, 1847) (Blattodea: Blattellidae) und ihre Verbreitung in der Schweiz. Revue Suisse de Zoologie 111(2): 395-424.

Bell, W. J., Roth, L. M. \& NALePA, C. A. (2007): Cockroaches: ecology, behavior, and natural history. The Johns Hopkins University Press, Baltimore: xvi $+230 \mathrm{pp}$.

Bodor, J. (2016): Potyautas vándorsáskák. Kertészet és szölészet 65(34): 26-27.

Brown, V. K. (1969): Aspects of the biology and growth of three species of Ectobius (Dictyoptera: Blattidae). Ph.D. Thesis, Univevsity of London: 398 pp.

Brown, V, K. (1973): The overwintering stages of Ectobius lapponicus (L.) (Dictyoptera: Blattidae). Journal of Entomology Series A, General Entomology 48: 11-24.

Galvagni, A. \& BARDiani, M. (2009): Ricerche sulle specie del genere Ectobius StePhENS, 1835, della corsica (Insecta Blattaria Ectobiidae). Atti della Accademia roveretana degli Agiati, fasc. B 8(9): 31-47.

Harz, K. (1976): Ordnung Blattoptera. In: Harz, K. \& Kaltenbach, A. (eds): Die Orthopteren Europas, Band 3. Junk, The Hague, pp. 169-305.

HoluŠA, J. \& KoČÁREK, P. (2000): Seasonal dynamics of the dusky cockroach Ectobius lapponicus (Blattodea, Blattellidae) in the eastern part of the Czech Republic. Biologia, Bratislava 55: 483486.

KÖHLER, G. (2006): Erstfund der Bernstein-Waldschabe, Ectobius vittiventris (A. CostA, 1847), in Thüringen (Insecta: Blattoptera, Blattellidae). Thüringer Faunistische Abhandlungen 11: 49-53.

Mueller, G., Landau Luescher, I. \& Schmidt, M. (2008): Temporal changes in the incidence of household Arthropod pests in Zurich, Switzerland. In: RoBinSON, W. H. \& BAJOMI, D. (ed.): Proceedings of the Sixth International Conference on Urban Pests. Executive Committee of the International Conference on Urban Pests, Veszprém, pp. 15-21.

MuRÁNYi D. \& PUSKÁs, G. (2018): Egy potenciális kertészeti kártevő, az Euborellia annulipes (LUCAS, 1847) fülbemászó (Dermaptera) faj hazai előfordulása. Növényvédelem 78(12): 513-517.

NAGY, B. (1970): Rearing of the European corn borer (Ostrinia nubialis HBN.) on a simplified artifical diet. Acta Phytopatologica Academiae Scientiarum Hungaricae 5(1): 73-79.

NAGY, B. (2016): Az egyenesszárnyú-gyüjtemény gyarapodása 2015-ben: NAGY BARNABÁs gyüjteménye (Acquisitions of the Orthoptera collection in 2015: the collection of BARNABÁs NAGY). Annales Musei historico-naturalis hungarici 108: 287-294.

PFeIFER, A. (2012): Die Bernstein-Waldschabe, Ectobius vittiventris (A. CosTA, 1847) hat RheinlandPfalz erreicht (Insecta: Blattodea). Mitteilungen der Pollichia 96: 63-65.

PusKÁs, G. (2018): Behurcolt Polyneoptera fajok Magyarországon. In: KisBENEdeK, T. (szerk.): 3. Magyar Orthopterás Találkozó. Programok, összefoglalók.2018. október 12. Pécs. Janus Pannonius Múzeum, Pécs, pp. 13-14.

Ramme, W. (1951): Zur Systematik, Faunistik und Biologie der Orthopteren von Südost-Europa und Vorderasien. Mitteilungen aus dem Zoologischen Museum in Berlin (1950) 27: 1-431 + 39 plates.

UÇKay, I., SaX, H., Longet-Di Pietro, S., Baur, H., Boulc'H, M.-F., AKaKPo, C., Chevrolet, J.-C. \& PitTET D. (2009): Cockroaches (Ectobius vittiventris) in an Intensive Care Unit, Switzerland. Emerging Infectious Diseases 15(3): 496-497. 
KINÁL F. \& PUSKÁS G.

VIDLIČKA, L. (2014): Ectobius vittiventris - new cockroach (Blattaria) for the fauna of Slovakia. Entomofauna Carpathica 26(1): 33-40.

VIDLIČKA, L. \& SzIRÁKI, Gy. (1997): The native cockoroaches (Blattaria) in the Carpathian Basin. Folia Entomologica Hungarica 58: 187-220.

Wassmer, G. T. \& PAge, T. L. (1993): Photoperiodic time measurement and a graded response in a cockroach. Journal of Biological Rhythms 8(1): 47-56.

Zimmermann, K. (2014): Scientific Experiences from Pest Advisory in Vorarlberg, Austria. In: MüLLeR, G., PospischiL, R. \& RoBInSON W. H. (eds): Proceedings of the 8th International Conference on Urban Pests. Executive Committee of the International Conference on Urban Pests, Veszprém, pp. 315-318. 


\title{
Occurrence of Ectobius vittiventris (Costa, 1847) (Blattellidae: Ectobiinae) in Hungary
}

\author{
FERENC KINÁL ${ }^{1}$ \& GELLÉRT PUSKÁS ${ }^{2}$ \\ 1E-mail: fkinalf.ferenc@gmail.com \\ ${ }^{2}$ Hungarian Natural History Museum, Department of Zoology, Baross u.13, \\ H-1088 Budapest, Hungary E-mail: puskas.gellert@nhmus.hu
}

\begin{abstract}
ÁLLATTANI KÖZLEMÉNYEK (2019) 104(1-2): 3-15.
\end{abstract}

\begin{abstract}
A new species for the Hungarian cockroach fauna, Ectobius vittiventris appeared in the parkland of Budapest, the first specimens were found in 2005. Based on its yearly regular data, this originally Mediterranean species seems to have an established population in the city and in its vicinity. Although E. vittiventris is not a synanthropic species, specimens often can be found in buildings, presumably because of the positive phototaxis. Therefore, it is often confused with Blattella germanica. The peak of swarming in Hungary is in September which is a bit later than observed in Switzerland. The length of the total development was between 6 and 14 months in our rearing experiments, the number of larval stages is seven. The length of development is probably also influenced by the seasonal length of daylight.
\end{abstract}

Keywords: entomology, faunistics, phenology, introduction, biological invasion.

Accepted: 17.04 .2019

Published online: .21 .05 .2019 